STUDIA I ARTYKUEY 



\section{WYKŁADNIA PRZEPISÓW W ZAKRESIE UDZIAŁU SPOŁECZEŃSTWA W OCHRONIE ŚRODOWISKA - WYBRANE PROBLEMY}

\section{Uwagi wstępne}

Zasada partycypacji publicznej jest aktualnie jedną z najważniejszych zasad funkcjonowania państwa demokratycznego i społeczeństwa obywatelskiego ${ }^{1}$. W związku z tym, jest ona zaliczana do podstawowych praw obywatelskich określonych w konstytucji ${ }^{2}$. Obowiązek konsultacji społecznych $w$ ramach zasady partycypacji jest obowiązkiem organów administracji publicznej.

Prawo ochrony środowiska jest tą dziedziną, w której procedura uspołeczniania procesu decyzyjnego, czyli partycypacja społeczna, powinna odgrywać istotną rolę. Procesy, jakie zachodzą w tym obszarze, nie mogą być prowadzone w oderwaniu od uczestnictwa mieszkańców danej wspólnoty lokalnej. Nie ulega wątpliwości, że udział obywateli i ich organizacji w ochronie środowiska wpływa na stworzenie wspólnego stanowiska, uzyskanie akceptacji mieszkańców, efektywniejszą realizację rozstrzygnięć, a w konsekwencji minimalizuje formy niezadowolenia członków danej jednostki. Dlatego też zasada partycypacji publicznej w rozwiązywaniu problemów środowiskowych jest jedną z fundamentalnych zasad prawa ochrony środowiska ${ }^{3}$.

\footnotetext{
* Dr hab., prof. Uniwersytetu Szczecińskiego; e-mail: anna.barczak@usz,edu.pl.

* Dr, Uniwersytet Szczeciński; e-mail: adrianna.ogonowska@usz.edu.pl.

1 Zob. P. Korzeniowski, Instytucje prawne ochrony środowiska a proces inwestycyjno-budowlany. Studium prawno-administracyjne, Warszawa 2012, s. 44.

2 Zob. P. Korzeniowski, Zasady prawne ochrony środowiska, Łódź 2010, s. 466.

3 Zob. M. Zakrzewska, Skarga powszechna w prawie ochrony środowiska, [w:] M. Rudnicki, A. Haładyj, K. Sobieraj (red.), Dekada harmonizacji w prawie ochrony środowiska, Lublin
} 2011, s. 81. 
Mając powyższe na uwadze należy zwrócić uwagę na wątpliwości prawne, jakie rodzą się w związku z powyższą partycypacją. Rozwiązaniu ich służy wykładnia przepisów prawnych dotyczących analizowanego udziału społeczeństwa. W zasadzie każdy jej rodzaj ma zastosowanie, z przewagą wykładni celowościowo-funkcjonalnej, co zostanie potwierdzone poniższymi rozważaniami.

Przedmiotem artykułu jest zatem omówienie pokrótce zasad wykładni prawa oraz jej rodzajów, zwrócenie uwagi na zastrzeżenia związane z wykładnią ustaleń terminologicznych dotyczących partycypacji publicznej w ochronie środowiska, a następnie analiza udziału organizacji ekologicznej w postępowaniu wymagającym udziału społeczeństwa. Opracowanie kończy wykładnia odpowiedniego stosowania przepisów (zapewniających udział społeczeństwa) dotyczących wyjątków od zasady udostępniania informacji o środowisku i jego ochronie.

\section{Wykładnia prawa i jej rodzaje}

Wykładnia prawa jest to interpretacja tekstów prawnych mająca na celu ustalenie rzeczywistego znaczenia przepisów i formułowanie na ich podstawie określonej normy postępowania ${ }^{4}$. „Przedmiotem wykładni są istniejące już przepisy prawne, z których dokonujący wykładni stara się wyprowadzić normy prawne" ${ }^{5}$. Jej celem natomiast jest wyprowadzenie (odkodowanie) hipotezy i dyspozycji normy prawnej. Wykładnia prawa jest zatem interpretacją wyrażeń języka prawnego i stanowi głównie wykluczenie występujących w nim wątpliwości. Podkreślić wyraźnie należy, że wykładnia prawa nie tworzy nowych przepisów i ich nie modyfikuje. Służy ona bowiem ustaleniu, jakie normy prawne są wysłowione w przepisach prawnych. Oznacza to, że jej charakter jest wtórny i pomocniczy wobec prawa obowiązującego.

4 Zob. M. Zieliński, Wykładnia prawa. Zasady, reguty, wskazówki, Warszawa 2010, s. 43 i nast.; A. Jamroza (red.), Wstęp do nauk prawnych, Białystok 1997, s. 149 i nast.; W. Jakimowicz, Wykładnia w prawie administracyjnym, Warszawa 2006, s. 16 i nast.; L. Morawski, Kilka uwag na temat wykładni, [w:] S. Wronkowska (red.), Polska kultura prawna a proces integracji europejskiej, Kraków 2005, s. 42.

5 S. Korycki, J. Kuciński, Z. Trzciński, J. Zaborowski, Zarys prawa, Warszawa 2005, s. 69. 
W doktrynie wskazuje się dwie funkcje, jakie powinna spełniać wykładnia prawa ${ }^{6}$ : „pierwsza to rola percepcyjna, przejawiająca się w rozumieniu (zrozumieniu) danego zwrotu, tj. uświadomieniu sobie jego sensu. Druga - rola dydaktyczna - jest związana z koniecznością lub co najmniej z ewentualnością przekładu zwrotów język $\mathrm{J}_{\mathrm{a}}$ (niezrozumiałych lub nie dość jasno zrozumiałych dla jakiegoś podmiotu P) na język J (zrozumiały lub precyzyjniej zrozumiały dla pomiotu $P$ ) "7.

Wykładnię prawa możemy ująć w dwojaki sposób: jako proces interpretacji prawa oraz jako rezultat tego procesu.

Wyróżnia się różne rodzaje prowadzenia wykładni w powyższych jej sposobach. W zakresie procesu interpretacji prawa możemy wyróżnić trzy jego etapy.

Za podstawowe i najważniejsze stadium tego procesu uznawana jest wykładnia językowa, tzn. ustalenie znaczenia przepisu prawnego ze względu na język, w jakim został on sformułowany. Wykładnia ta ma pierwszeństwo przed innymi rodzajami wykładni. Od niej zaczyna się proces interpretacji przepisów prawnych. Dyrektywami specyficznymi dla interpretacji wykładni językowej są: dyrektywa domniemania języka potocznego, dyrektywa domniemania uniwersalnego języka prawnego, dyrektywa tożsamości znaczeniowej, dyrektywa kompletności ${ }^{8}$.

W przypadku, gdy próby dokonania ustalenia sensu tego przepisu nie powiodą się z uwagi na kilka rozbieżnych jego znaczeń, zastosowanie ma wykładnia systemowa. Jej celem jest ustalenie znaczenia przepisu prawnego ze względu na miejsce, jakie zajmuje on w systemie prawa. Dyrektywami specyficznymi powyższej wykładni są: dyrektywa niesprzeczności, dyrektywa priorytetu zasady prawa, dyrektywa normatywności zasady prawa, dyrektywa korelacji systemu prawa, dyrektywa systematyzacji wewnętrznej aktu prawnego'.

Jeżeli na podstawie wykładni językowej oraz systemowej nie uda się ustalić znaczenia przepisu prawnego, wówczas może być zastoso-

6 Zob. M. Zieliński, Wykładnia prawa. Zasady..., s. 227.

7 Tamże, s. 229.

8 Zob. M. Zirk-Sadowski, Problemy wykładni językowej w prawie administracyjnym, [w:] R. Hauser, Z. Niewiadomski, A. Wróbel (red.), System prawa administracyjnego, t. 4. L. Leszczyński, B. Wojciechowski, M. Zirk-Sadowski, Wykładnia w prawie administracyjnym, Warszawa 2012, s. 179-208.

9 Zob. L. Leszczyński, Wykładnia systemowa przepisów prawa administracyjnego, [w:] R. Hauser, Z. Niewiadomski, A. Wróbel (red.), System prawa..., s. 209-261. 
wana wykładnia celowościowo-funkcjonalna ${ }^{10}$. „Wykładnia ta zakłada, by przyjąć takie rozumienie przepisów prawa, żeby w sposób możliwie pełny prawo realizowało cele ustawodawcy"11. Z powyższego wynika, że w tej wykładni występują dwie reguły, tj. celowościowe oraz funkcjonalne. Reguły celowościowe wykładni odwołują się do kategorii celu, jaki był lub jest związany z działalnością prawodawczą. Istotne jest, czy cel jest wyraźnie sformułowany, czy nie. Wykładnia celowościowa zatem aktualizuje założenie o racjonalności prawodawcy i racjonalności rezultatu prac prawodawczych ${ }^{12}$. Reguły funkcjonalne natomiast mają zastosowanie wtedy, gdy, wobec braku precyzyjnie ustalonego znaczenia danego przepisu, po przeprowadzeniu wykładni językowej i systemowej, należy wybrać jedno z kilku możliwych znaczeń. W przypadku, gdy mamy kilka językowo możliwych znaczeń oraz znany jest nam system wartości, którym kierował się ustawodawca ustanawiając dany przepis, to należy wybrać takie znaczenie, które nie powoduje skutków społecznych naruszających ten system wartości i przy którym miałby on najlepsze uzasadnienie aksjologiczne ${ }^{13}$. W literaturze przedmiotu wyróżnia się dwa rodzaje wykładni funkcjonalnej: statyczną i dynamiczną.

Wyraźnie należy podkreślić, że trzy powyższe rodzaje wykładni prawa charakteryzują się chronologiczną kolejnością ich stosowania. Oznacza to, że najpierw stosuje się wykładnię językową, następnie systemową i wreszcie celowościowo-funkcjonalną ${ }^{14}$.

Jeżeli chodzi o wykładnię jako rezultat procesu interpretacji prawa to wyodrębnić można trzy rodzaje wykładni: wykładnia literalna (dosłowna), wykładnia rozszerzająca oraz wykładnia zawężająca.

10 Zob. L. Leszczyński, Wykładnia celowościowo-funkcjonalna przepisów prawa administracyjnego, [w:] R. Hauser, Z. Niewiadomski, A. Wróbel (red.), System prawa..., s. 263-303.

11 B. Brzeziński, Wstęp do nauki prawa podatkowego, Torun 2003, s. 207.

12 Zob. np. wyrok NSA w Warszawie z dnia 15 maja 2008 r., II OSK 548/07, Centralna Baza Orzeczeń Sądów Administracyjnych (CBOSA), http://orzeczenia.nsa.gov.pl/doc/ F460921839 [dostęp: 13.11.2018 r.], w którym stwierdza się: „Domniemanie racjonalności prawodawcy jest jednym z najczęściej powoływanych domniemań interpretacyjnych przez polskie Sądy. Trybunał Konstytucyjny domniemanie racjonalności prawodawcy uważa wręcz za niezbędne założenie każdej interpretacji przepisów prawnych (por. orzeczenie TK z dnia 25 lutego 1992 r., sygn. K 3/91, OTK 1992/1/34)”.

13 Zob. A. Jamroza (red.), Wstęp do nauk..., s. 159.

14 Zob. M. Zieliński, Wybrane zagadnienia wykładni prawa, „Państwo i Prawo” 2009, nr 6, s. 8 . 
Wykładnia literalna ma zastosowanie wówczas, gdy pośród możliwych znaczeń przepisu, które otrzymano jako wynik przeprowadzenia odmiennych wykładni, wybieramy znaczenie będące rezultatem zastosowania reguł znaczeniowych (semantycznych) i składniowych (syntaktycznych) języka ${ }^{15}$.

Wykładnia rozszerzająca ma zastosowanie wtedy, gdy pośród znaczeń przepisu powstałych po zastosowaniu różnych dyrektyw interpretacyjnych, wybierzemy rozumienie wynikające $\mathrm{z}$ dyrektyw pozajęzykowych i jest ono szersze od rozumienia językowego.

Z kolei wykładnia zawężająca ma miejsce, gdy spośród różnych zakresów normy wybieramy rozumienie powstałe po zastosowaniu dyrektyw wykładni systemowej lub funkcjonalnej, które jest węższe od rozumienia językowego.

Innym podziałem wykładni prawa jest jej klasyfikacja z uwagi na podmiot jej dokonujący. W tym zakresie wyróżnia się: wykładnię autentyczną, wykładnię legalną oraz wykładnię doktrynalną ${ }^{16}$. Wykładnia autentyczna polega na tym, że dokonuje jej organ tworzący prawo. Wykładnia legalna to wykładnia, do dokonywania której upoważniony jest - przez przepis prawa - organ państwa. Wykładnia doktrynalna natomiast dokonywana jest przez prawników. O ile dwie pierwsze wykładnie mają powszechną moc wiążącą (erga omnes), o tyle ta ostatnia wykładnia nie ma mocy wiążącej.

W doktrynie wskazuje się także na wykładnię merytoryczną i wykładnię formalną. Taki podział wprowadza M. Zieliński ${ }^{17}$.

Wykładnia merytoryczna $\mathrm{w}$ ujęciu pragmatycznym to określony zespół czynności interpretacyjnych zrealizowany zgodnie z przyjętymi w naszej kulturze prawnej regułami. W ujęciu apragmatycznym wykładnia jest wykładnią merytoryczną, jeżeli otrzymany rezultat (treść normy) jest wynikiem rzeczywiście poprawnego zastosowania kulturowo zaakceptowanych reguł.

Wykładnia formalna jest zespołem czynności interpretacyjnych przez jakiś wyróżniony prawnie podmiot, np. sąd (wersja pragmatyczna), bądź też rezultatem interpretacji zrealizowanej przez ten podmiot (wersja

15 Zob. L. Leszczyński, Zagadnienia teorii stosowania prawa. Doktryna i tezy orzecznictwa, Kraków 2001, s. 123; A. Jamroza (red.), Wstęp do nauk..., s. 159.

16 Zob. A. Jamroza (red.), Wstęp do nauk..., s. 161; Z. Ziembiński, Zadania i moc wiążąa aktów wykładni, [w:] S. Wronkowska, Z. Ziembiński, Zarys teorii prawa, Poznań 1997, s. 160.

17 Zob. M. Zieliński, Wykładnia prawa. Zasady..., s. 63-66. 
apragmatyczna) $\mathrm{w}$ procesie realizowania się zdarzeń prawnych, a więc przede wszystkim $\mathrm{w}$ procesie stosowania prawa ${ }^{18}$.

\section{Wykładnia ustaleń terminologicznych}

\section{1. „Każdy”}

W pierwszej kolejności należy wskazać, że na gruncie języka polskiego "każdy” to zaimek komunikujący, że to, o czym jest mowa w zdaniu, odnosi się do osób, przedmiotów lub zjawisk danej grupy, z jednoczesnym założeniem, że nie ma takich, do których by się to nie odnosiło ${ }^{19}$. Istotne jest to, że na gruncie polskiego ustawodawstwa ${ }^{20}$ interpretacji pojęcia „każdy” należy każdorazowo dokonywać z uwzględnieniem art. 37 Konstytucji Rzeczypospolitej Polskiej z dnia 2 kwietnia 1997 r. ${ }^{21}$ W konsekwencji „,każdym” jest ten „kto znajduje się pod władzą Rzeczypospolitej Polskiej" bez względu na posiadanie polskiego obywatelstwa lub innych cech, w tym np. pełnej zdolności do czynności prawnych. Analizowane prawo składania uwag i wniosków przysługuje również cudzoziemcom i bezpaństwowcom, co jest związane z zasadą powszechności². Należy zatem przyznać słuszność stwierdzeniu, że „każdym” jest osoba legalnie przebywająca na terytorium RP i korzystająca z wolności i praw przyznanych Konstytucją RP23.

Należy zasygnalizować, że „każdym” nie są osoby posiadające interes prawny $\mathrm{w}$ postępowaniu, ponieważ, gdyby taki interes posiadały,

18 Zob. tamże, s. 63-64.

19 Stownik języka polskiego, http://sjp.pwn.pl/sjp/;2524005 [dostęp: 11.12.2017 r.].

${ }^{20} \mathrm{~W}$ tym przypadku pojęcie „każdy” pojawia się w art. 29 ustawy z dnia 3 października 2008 r. o udostępnianiu informacji o środowisku i jego ochronie, udziale społeczeństwa w ochronie środowiska oraz o ocenach oddziaływania na środowisko, tekst jednolity: Dz. U. z 2018 r. poz. 2081 z późn. zm. (dalej: u.o.o.ś.).

${ }^{21}$ Konstytucja Rzeczypospolitej Polskiej z dnia 2 kwietnia 1997 r., Dz. U. z 1997 r. Nr 78, poz. 483 z późn. zm. (dalej: Konstytucja RP).

22 Zob. D. Kościuk [w:] T. Filipowicz, A. Plucińska-Filipowicz, M. Wierzbowski (red.), Ustawa o udostępnianiu informacji o środowisku i jego ochronie, udziat społeczeństwa w ochronie środowiska oraz oceny oddziaływania na środowisko. Komentarz, Warszawa 2017, s. 211.

${ }_{23}$ Zob. M. Nowak, B. Dąbrowski, Ustawa o udostępnianiu informacji o środowisku i jego ochronie, udział społeczeństwa w ochronie środowiska oraz oceny oddziaływania na środowisko. Komentarz praktyczny, Warszawa 2013, s. 17. 
byłyby jego stroną ${ }^{24}$. Warto również dodać, że interes prawny dotyczy szeroko rozumianej sytuacji prawnej podmiotu prawa, wyznaczonej normami prawnymi różnego rodzaju, z których wynikają jego uprawnienia, obowiązki, korzyści lub wolności prawnie chronione. Jednocześnie, jak wskazuje się $\mathrm{w}$ orzecznictwie sądów administracyjnych ${ }^{25}$, stwierdzenie istnienia interesu prawnego sprowadza się do ustalenia związku o charakterze materialno-prawnym między normą prawa materialnego a sytuacją prawną konkretnego podmiotu prawa. Warto przywołać również wyrok Naczelnego Sądu Administracyjnego z dnia 9 kwietnia 2013 r. ${ }^{26}$, który wprost wskazuje, że posiadania statusu strony $\mathrm{w}$ rozumieniu art. 28 k.p.a. nie należy mylić i utożsamiać z możliwością składania uwag i wniosków w toku postępowania przez każdy zainteresowany podmiot. W tym miejscu należy również wskazać, że stronę postępowania administracyjnego powinna cechować pełna zdolność do czynności prawnych, natomiast "każdym" może być osoba fizyczna zarówno nieposiadająca zdolności do czynności prawnych albo posiadająca jedynie ograniczoną zdolność do czynności prawnych.

W literaturze przedmiotu podkreśla się, że natura prawa składania uwag i wniosków w postępowaniach wymagających udziału społeczeństwa, umożliwia korzystanie z niego podmiotom również innym niż osoby fizyczne ${ }^{27}$. W rezultacie pojęcie „każdy” jest pojęciem szerszym niż pojęcie „społeczeństwo" 28 . Należy dodać, że „każdym” mogą być zarówno osoby fizyczne, osoby prawne, jednostki organizacyjne nieposiadające osobowości prawnej, jak i grupy osób fizycznych. Jednocześnie warto zwrócić uwagę również na możliwość składania uwag i wniosków przez organizacje i instytucje społeczne, nawet te realizujące zadania zlecone z zakresu administracji publicznej, gdyż wskazane przyjęcie zadań nie prowadzi do pozbawienia statusu adresata konstytucyjnych praw i wolności ${ }^{29}$.

24 Zob. A. Haładyj, Udział społeczeństwa w strategicznej ocenie oddziaływania na środowisko jako instytucji prawa ochrony środowiska, Lublin 2015, s. 76.

25 Zob. wyrok WSA w Kielcach z dnia 28 czerwca 2017 r., II SA/Ke164/17, LEX nr 2325102.

26 Wyrok NSA w Warszawie z dnia 9 kwietnia 2013 r., II OSK 2396/11, LEX nr 1337355.

${ }^{27}$ Zob. M. Florczak-Wątor [w:] M. Safjan, L. Bosek (red.), Konstytucja RP. Komentarz, t. 1, Warszawa 2016, s. 1451.

28 Zob. A. Haładyj, Udział społeczeństwa..., s. 77-78.

29 Zob. D. Kościuk [w:] T. Filipowicz, A. Plucińska-Filipowicz, M. Wierzbowski (red.), Ustawa o udostępnianiu informacji..., s. 212-213. 
W rezultacie ustalając znaczenie pojęcia „każdy”, oprócz wykładni językowej, posłużyć się należy dyrektywami systemowymi oraz funkcjonalnymi wykładni.

\section{2. „Postępowanie wymagające udziału społeczeństwa”}

Zarówno prawo składania uwag i wniosków, jak i prawo uczestniczenia organizacji ekologicznych $\mathrm{w}$ postępowaniach na prawach strony, dotyczy wyłącznie postępowań wymagających udziału społeczeństwa. Natomiast pojęcie "postępowanie wymagające udziału społeczeństwa” może wywoływać pewne wątpliwości, dlatego warto poświęcić jego analizie chwilę uwagi. Nie ulega wątpliwości, że postępowania wymagające udziału społeczeństwa powinny cechować się dołożeniem $\mathrm{w}$ trakcie ich trwania wszelkich starań, aby społeczeństwo mogło przedstawić swoje zdanie, zwłaszcza poprzez składanie uwag i wniosków. Należy jednak wskazać, że ani u.o.o.ś., ani inna ustawa, nie zawiera definicji legalnej pojęcia „postępowanie wymagające udziału społeczeństwa”. Zauważyć należy również, że w żadnym akcie prawa powszechnie obowiązującego nie znajduje się przepis prawny zawierający wyliczenie o charakterze enumeratywnym albo przykładowym tego typu postępowań.

W rezultacie postępowaniami wymagającymi udziału społeczeństwa są postępowania administracyjne z zakresu ochrony środowiska, dla których ustawodawca wyraźnie i wprost przewidział taką możliwość przepisami prawa materialnego ${ }^{30}$, co znajduje potwierdzenie również $\mathrm{w}$ orzecznictwie sądów administracyjnych ${ }^{31}$. W literaturze przedmiotu wskazuje się również, że w ramach postępowania wymagającego udziału społeczeństwa, oprócz zespołu czynności objętych przepisami postępowania administracyjnego sensu stricto będącego postępowaniem jurysdykcyjnym, mieszczą się również zespoły czynności wynikające z przepisów regulujących udział społeczeństwa w postępowaniach administracyjnych sensu largo w zakresie ocen oddziaływania na środowisko ${ }^{32}$. Biorąc pod

30 Zob. M. Nowak, B. Dąbrowski, Ustawa o udostępnianiu informacji..., s. 58; D. Kościuk [w:] T. Filipowicz, A. Plucińska-Filipowicz, M. Wierzbowski (red.), Ustawa o udostępnianiu..., s. 210-211.

31 Zob. wyrok WSA w Szczecinie z dnia 14 stycznia 2016 r., II SA/Sz 1097/15, LEX nr 1996661.

32 Zob. A. Haładyj, Udział społeczeństwa..., s. 66-67. 
uwagę powyższe, stwierdzić należy, że również w przypadku interpretacji tego pojęcia kluczowe znaczenie odgrywają dyrektywy funkcjonalne wykładni.

Tytułem przykładu postępowania wymagającego udziału społeczeństwa, warto wskazać na art. 79 u.o.o.ś., zgodnie z którym przed wydaniem decyzji o środowiskowych uwarunkowaniach organ właściwy do jej wydania zapewnia możliwość udziału społeczeństwa w postępowaniu, $\mathrm{w}$ ramach którego przeprowadza ocenę oddziaływania przedsięwzięcia na środowisko.

Dodać należy, że obowiązek ustalenia, czy dane postępowanie jest postępowaniem wymagającym udziału społeczeństwa, obciąża organy administracji, do których złożone zostały uwagi i wnioski lub do których organizacja ekologiczna zgłosiła chęć uczestniczenia w postępowaniu.

\section{3. „Organizacja ekologiczna" i jej „cel statutowy”}

Przed dokonaniem wykładni partycypacji organizacji ekologicznej $\mathrm{w}$ postępowaniach wymagających udziału społeczeństwa niezbędne jest dokonanie wykładni pojęć „,organizacja ekologiczna” oraz „cel statutowy”. W pierwszej kolejności należy wskazać, że pojęcie „organizacja ekologiczna" zostało zdefiniowane w art. 3 ust. 1 pkt 10 u.o.o.ś. jako organizacja społeczna, której statutowym celem jest ochrona środowiska. Natomiast pojęcie „organizacja społeczna”, zgodnie z art. $5 \S 2$ pkt 5 k.p.a., oznacza organizacje zawodowe, samorządowe, spółdzielcze i inne organizacje społeczne, co wskazuje na otwarty charakter niniejszej definicji oraz jej bardzo szeroki zakres przedmiotowy ${ }^{33}$. Biorąc pod uwagę przywołaną definicję, wskazać należy, że każda organizacja ekologiczna jest organizacją społeczną, ale nie każda organizacja społeczna posiada status ekologicznej.

W tym miejscu warto również zasygnalizować - wskazane przez K. Gruszeckiego i pomocne w interpretacji pojęcia „organizacji ekologicznej" - przesłanki uznania podmiotu za organizację ekologiczną, do których zalicza się: wyodrębnienie organizacyjne, legalną działalność oraz prowadzenie działalności w zakresie ochrony środowiska. Dodatkowo z analizy

33 Zob. K. Gruszecki, Ustawa o udostępnianiu informacji o środowisku i jego ochronie, udziat społeczeństwa w ochronie środowiska oraz oceny oddziatywania na środowisko. Komentarz, Wrocław 2009, s. 118. 
orzecznictwa sądowoadministracyjnego ${ }^{34}$ wywieść należy, że status organizacji ekologicznych może zostać przyznany fundacjom prowadzącym działalność w zakresie ochrony środowiska, natomiast nie ma podstaw do nadania go partiom politycznym ${ }^{35}$ czy izbom gospodarczym. Należy jednak zauważyć, że polskie regulacje prawne dopuszczają możliwość prowadzenia działalności przez organizacje ekologiczne w różnych formach prawnych. Reasumując analizowaną kwestię należy wskazać, że wykładnię pojęcia „organizacja ekologiczna” ułatwia możliwość korzystania z dyrektyw językowych w postaci definicji legalnych występujących w obowiązującym porządku prawnym. Dodatkowo ustalenia znaczenia pojęcia "organizacja ekologiczna" ułatwia jednolitość poglądów w tym zakresie występująca w nauce prawa oraz orzecznictwie sądowoadministracyjnym.

Warto odnieść się również do przedmiotu działalności organizacji ekologicznych, który odróżnia je od innych organizacji społecznych. Należy wskazać, że działalność w zakresie ochrony środowiska nie musi stanowić jedynego celu statutowego ${ }^{36}$ oraz może dotyczyć szeroko rozumianej ochrony środowiska lub przyrody, jak również poszczególnych jej elementów lub podejmowanych działań proekologicznych. W orzecznictwie podkreśla się, że następstwem tak szerokiego ujęcia ochrony środowiska jest fakt, że liczba spraw mieszczących się w tej kategorii jest bardzo duża, w związku z czym również udział organizacji ekologicznych w postępowaniu administracyjnym może być bardzo szeroki ${ }^{37}$. W rezultacie podczas oceny określanych w statucie celów należy każdorazowo stosować wykładnię celowościowąa ${ }^{38}$.

Na gruncie obecnie obowiązującego stanu prawnego organizacja ekologiczna, dokonująca zgłoszenia swojego udziału w postępowaniu, wskazuje na postanowienia swojego statutu w celu udowodnienia prowadzenia

34 Zob. wyrok WSA w Warszawie z dnia 11 sierpnia 2010 r., IV SA/Wa 857/10, LEX nr 759044; uchwała SN z dnia 12 grudnia 2005 r., II OPS 4/05, LEX nr 167966.

35 Zob. B. Opaliński [w:] B. Opaliński (red.), Ustawa o udostępnianiu informacji o środowisku i jego ochronie, udziat społeczeństwa w ochronie środowiska oraz oceny oddziatywania na środowisko. Komentarz, Warszawa 2016, s. 91-92.

36 Zob. W. Jacyno, J. Rewkowska [w:] T. Filipowicz, A. Plucińska-Filipowicz, M. Wierzbowski (red.), Ustawa o udostepnianiu informacji..., s. 52-53.

37 Zob. wyrok WSA w Kielcach z dnia 4 grudnia 2013 r., II SA/Ke 920/13, LEX nr 1426855.

38 Zob. wyrok NSA w Warszawie z dnia 13 grudnia 2011 r., II OSK 1732/10, LEX nr 1152019. 
działalności w zakresie ochrony środowiska. Jednak w związku z dopuszczalnością uznania za organizację ekologiczną podmiotów podejmujących działalność w różnych formach prawnych (co wynika z szerokiego rozumienia pojęcia „organizacji ekologicznej”), należy wskazać, że nie każdy $\mathrm{z}$ tych podmiotów posiada statut. W tym miejscu wskazać należy, że pojęcie „statut" to pojęcie języka prawnego, które używane jest dla oznaczenia aktu wewnętrznego (ustrojowego) o charakterze założycielskim określającego strukturę, zadania i sposób działania instytucji lub organizacji ${ }^{39}$. Tytułem przykładu warto dodać, że aktem założycielskim stowarzyszenia rejestrowego jest statut, natomiast stowarzyszenia zwykłego - regulamin. Dokonując wykładni literalnej pojęcia "statut” należałoby stwierdzić, że „statutem” w rozumieniu art. 33 ust. 1 u.o.o.ś. są wyłącznie akty założycielskie noszące nazwę "statut". W przypadku analizowanego przepisu prawnego, racjonalnym i uzasadnionym byłoby jednak dokonanie wykładni celowościowej, czyli odwołującej się do kategorii celu. Wówczas, zarówno statut, jak i inne akty założycielskie mające tożsame cele i znaczenie, będą traktowane jako "statut" w rozumieniu art. 33 ust. 1 u.o.o.s. ${ }^{40}$ W rezultacie, biorąc pod uwagę powyższe rozważania, należy wskazać, że w przypadku definiowania pojęcia „cel statutowy” konieczne jest dokonanie wykładni rozszerzającej.

\section{Wykładnia partycypacji organizacji ekologicznej w postępowaniach wymagających udziału społeczeństwa}

Prawo ochrony środowiska zakłada ingerencję państwa w zjawiska i procesy środowiskowe oraz określa jej zakres i sposoby tej ingerencji. Jest ona bardziej wyraźna i głębsza, niż ma to miejsce w innych dziedzinach prawa. W związku z powyższym procedura uspołeczniania procesu decyzyjnego, czyli partycypacja społeczna, powinna odgrywać istotną rolę. Procesy, jakie zachodzą w tym obszarze, nie mogą być prowadzone

39 Internetowy słownik języka polskiego, http://sjp.pwn.pl/sjp/;2524005 [dostęp: 11.12.2017 r.]; W. Jacyno, J. Rewkowska [w:] T. Filipowicz, A. Plucińska-Filipowicz, M. Wierzbowski (red.), Ustawa o udostęnianiu informacji, s. 256-257.

40 Zob. W. Jacyno, J. Rewkowska [w:] T. Filipowicz, A. Plucińska-Filipowicz, M. Wierzbowski (red.), Ustawa o udostęnianiu informacji, s. 52-53; wyrok NSA w Warszawie z dnia 21 czerwca 2016 r., II OSK 2563/14, LEX nr 2106685. 
w oderwaniu od uczestnictwa mieszkańców danej wspólnoty lokalnej. Nie ulega wątpliwości, że udział obywateli i ich organizacji w ochronie środowiska wpływa na stworzenie wspólnego stanowiska, uzyskanie akceptacji mieszkańców, efektywniejszą realizację rozstrzygnięć, a w konsekwencji minimalizuje formy niezadowolenia członków danej jednostki.

Dokonując interpretacji udziału organizacji ekologicznej w postępowaniach z zakresu ochrony środowiska, należy głównie kierować się wykładnią celowościowo-funkcjonalną, zwłaszcza elementem celowości, który jest podstawowy w tej wykładni.

Organizacja ekologiczna $\mathrm{w}$ postępowaniach wymagających udziału społeczeństwa występuje $\mathrm{w}$ różnych postaciach, w zależności od tego, czy mamy do czynienia z postępowaniem legislacyjnym czy administracyjnym.

Udział organizacji ekologicznych w powyższych postępowaniach będzie dość szeroki, z uwagi na to, że pojęcie ochrony środowiska ma bardzo szeroki zakres przedmiotowy ${ }^{41}$.

Z kolei w postępowaniu administracyjnym wymagającym udziału społeczeństwa, organizacja ekologiczna będzie występowała na uprzywilejowanych zasadach. W myśl art. 44 ust. 1 u.o.o.ś. organizacja ekologiczna, powołująca się na swoje cele statutowe, zgłaszająca chęć uczestniczenia w określonym postępowaniu wymagającym udziału społeczeństwa oraz prowadząca działalność statutową przez minimum 12 miesięcy przed dniem wszczęcia tego postępowania, uczestniczy w nim na prawach strony ${ }^{42}$. Należy wyraźnie podkreślić, że organizacja ekologiczna nie staje się stroną postępowania, ale podmiotem, któremu przysługują jedynie analogiczne uprawnienia. Udział organizacji ekologicznej na prawach strony dotyczy tylko postępowań administracyjnych. Jeżeli natomiast chodzi o postępowanie związane z przyjmowaniem określonych dokumentów, organizacje ekologiczne mają uprawnienia analogiczne $\mathrm{z}$ innymi podmiotami - są objęte zwrotem „każdy”, dotyczącym składania uwag i wniosków.

${ }^{41}$ Na temat pojęcia „ochrona środowiska”, zob. M. Górski, M. Pchałek, W. Radecki, J. Jerzmański, M. Bar, S. Urban, J. Jendrośka, Prawo ochrony środowiska. Komentarz, Warszawa 2011, s. 80-82; M. Górski [w:] J. Jendrośka, Ustawa - Prawo ochrony środowiska. Komentarz, Wrocław 2001, s. 53-57; B. Rakoczy [w:] Z. Bukowski, E.K. Czech, K. Karpus, B. Rakoczy, Prawo ochrony środowiska. Komentarz, Warszawa 2013, s. 50-51; B. Rakoczy [w:] J. Ciechanowicz-McLean, Z. Bukowski, B. Rakoczy, Prawo ochrony środowiska. Komentarz, Warszawa 2008, s. 47-48.

${ }^{42}$ Wyrok WSA w Gorzowie Wielkopolskim z dnia 13 października 2017 r., II SA/Go 889/17, LEX nr 2387827. 
Organizacja ekologiczna, uczestnicząc $\mathrm{w}$ postępowaniu na prawach strony, może podejmować tylko „czynności procesowe, ale nie może dysponować prawami o charakterze materialnym, które są przedmiotem postępowania w sprawie innej osoby. $Z$ tego też względu nie może skutecznie zabiegać o zawieszenie postępowania na podstawie art. $98 \S 1$ k.p.a. ${ }^{43}$, ani o umorzenie postępowania na mocy art. $105 \S 2$ k.p.a. Nie może też powodować rozporządzenia prawami strony lub zabiegającej o taki status na podstawie art. $145 \S 1$ pkt 4 k.p.a., bez pogwałcenia zasady dyspozycyjności" ${ }^{44}$.

Aby organizacja ekologiczna mogła wziąć udział w postępowaniu administracyjnym wymagającym udziału społeczeństwa, powinna zgłosić chęć uczestniczenia $\mathrm{w}$ takim postępowaniu. Nie ma tu zastosowania art. $31 \S 4$ k.p.a. W związku z powyższym należy wskazać, że art. 44 ust. 1 u.o.o.ś. stanowi lex specialis wobec przepisu art. 31 k.p.a. ${ }^{45}$ Ustawodawca nie określił, $w$ jakiej formie powinno to nastąpić oraz jakie wymagania formalne powinien taki wniosek spełniać. Postępowanie, w którym organizacje ekologiczne mogą zgłaszać swój udział, jest tylko rodzajem postępowania administracyjnego - stąd też zastosowanie winien mieć art. 63 § 1 k.p.a. Zgodnie z nim, podania (gdzie wniosek o dopuszczenie do udziału $\mathrm{w}$ postępowaniu jest jedną z jego form) mogą być wnoszone na piśmie, telegraficznie lub za pomocą dalekopisu, telefaksu, poczty elektronicznej albo za pomocą formularza umieszczonego na stronie internetowej właściwego organu administracji publicznej, umożliwiającego wprowadzenie danych do systemu teleinformatycznego tego organu, a także ustnie do protokołu. O skuteczności zgłoszenia wniosku decyduje to, że takiego zgłoszenia winien dokonać podmiot upoważniony do reprezentowania wnoszącej go organizacji w obrocie prawnym. Wniosek taki musi spełniać wymagania formalne wynikające $z$ art. $63 \S 3$ i 3a k.p.a.

$\mathrm{W}$ istniejącym porządku prawnym ustawodawca nie wymaga, aby do zgłoszenia udziału były dołączone uwagi lub wnioski. Ich złożenie jest niezależne od zgłoszenia woli uczestniczenia w postępowaniu ${ }^{46}$.

43 Ustawa z dnia 14 czerwca 1960 r. - Kodeks postępowania administracyjnego, tekst jednolity: Dz. U. z 2017 r. poz. 1257 (dalej: k.p.a.).

44 J. Borkowski, Glosa do wyroku NSA z dnia 23 listopada 1999 r., II SA Kr 1191/99, „Orzecznictwo Sądów Polskich” 2000, z. 7/8, poz. 112.

45 Zob. wyrok NSA z dnia 29 listopada 2016 r., II OSK 524/15, CBOSA [dostęp: 13.11.2018 r.].

46 Zob. B. Draniewicz, Glosa do wyroku WSA z dnia 22 lipca 2012 r., II Sa/Kr 272/10, „Prawo i Środowisko" 2010, nr 3, s. 110-119. 
Dopuszczenie organizacji ekologicznej do udziału w postępowaniu nie wymaga wydania postanowienia ${ }^{47}$.

Organizacja ekologiczna może przystąpić do postępowania w każdym jego stadium, przy czym warunkiem bezwzględnym jest, jak zaznaczono powyżej, statutowe zainteresowanie sprawami ochrony środowiska oraz udział w obrocie prawnym przez 12 miesięcy od dnia wszczęcia postępowania. Nie obowiązuje bowiem pośrednio zakreślony 30-dniowy termin na zgłaszanie uwag lub wniosków ${ }^{48}$. Organ ma możliwość odmówienia dopuszczenia do udziału $\mathrm{w}$ postępowaniu takiej organizacji. Czyni to $\mathrm{w}$ formie postanowienia, na które służy zażalenie. Ustawodawca nie wskazuje przyczyn odmowy uczestnictwa. Wydaje się jednak, że przyczyną odmowy może być niewykazanie statutowego zainteresowania sprawami ochrony środowiska. Przyczynę może również stanowić uznanie przez organ, że zgłaszający się podmiot nie ma statusu organizacji ekologicznej.

Dość wątpliwie uregulowane zostały instrumenty prawne przysługujące organizacjom ekologicznym, zawarte w art. 44 ust. 2 i 3 u.o.o.ś. Pierwszym środkiem prawnym przysługującym organizacji ekologicznej jest przyznanie jej prawa do złożenia odwołania od decyzji wydanej w postępowaniu wymagającym udziału społeczeństwa, jeżeli jest to uzasadnione celami statutowymi tej organizacji, także w przypadku, gdy nie brała ona udziału w określonym postępowaniu wymagającym udziału społeczeństwa prowadzonym przez organ pierwszej instancji. Wniesienie odwołania ustawa uznaje za równoznaczne ze zgłoszeniem chęci uczestniczenia $w$ takim postępowaniu odwoławczym. Zestawiając te regulacje z art. 127 § 1 k.p.a. (przyznającym prawo do złożenia odwołania stronie postępowania, czyli podmiotowi spełniającemu cechy określone w art. 28 k.p.a.), należy stwierdzić, że na gruncie art. 44 ust. 1 u.o.o.ś., organizacja ekologiczna działa na prawach strony. Oznacza to, że nie jest ona stroną postępowania, a legitymację do złożenia odwołania uzyskuje przez uzyskanie uprawnień strony w postępowaniu pierwszej instancji ${ }^{49}$.

47 Zob. wyrok WSA we Wrocławiu z dnia 27 maja 2010 r., II SA/Wr 89/10, LEX nr 674622 .

48 Zob. B. Draniewicz, tamże.

49 Zob. M. Górski, Aktualne regulacje prawne w zakresie ochrony środowiska, wedtug stanu prawnego na koniec stycznia 2009 r., Poznań 2009, s. 26; zob. także wyrok NSA w Warszawie z dnia 9 sierpnia 2016 r., II OSK 2237/15, LEX nr 2142364. 
Drugim środkiem prawnym przysługującym organizacji ekologicznej (budzącym kontrowersje) jest skarga do sądu administracyjnego od decyzji wydanej w postępowaniu wymagającym udziału społeczeństwa, jeżeli jest to uzasadnione celami statutowymi tej organizacji, także w przypad$\mathrm{ku}$, gdy nie brała ona udziału $\mathrm{w}$ określonym postępowaniu wymagającym udziału społeczeństwa. Ostatnia część przepisu sugeruje, że uprawnienia skargowe przysługują organizacji ekologicznej bez względu na to, czy brała udział we wcześniejszych etapach postępowaniach. Regulacja ta sprzeczna jest zwłaszcza z art. 50 § 1 ustawy Prawo o postępowaniu przed sądami administracyjnymi. Zgodnie z jego postanowieniem organizacja społeczna może złożyć skargę w sprawie, w której brała udział $\mathrm{w}$ postępowaniu administracyjnym. Ponadto, według art. $52 \S 1$ ustawy Prawo o postępowaniu przed sądami administracyjnymi, skargę można wnieść po wyczerpaniu środków zaskarżenia, jeżeli służyły one skarżącemu w postępowaniu przed organem właściwym w sprawie. $Z$ powyższego wynika, że art. 44 ust. 3 u.o.o.ś. jest wyraźnie sprzeczny z postanowieniami ustawy Prawo o postępowaniu przed sądami administracyjnymi. Jak zaznaczono w piśmiennictwie, wprowadza on wyjątek od zasad generalnych nie do końca chyba uzasadniony ${ }^{50}$. Sąd administracyjny natomiast uważa, że przepis art. 44 ust. 3 ustawy o udziale społeczeństwa stanowi lex specialis w stosunku do art. $50 \S 1$ ustawy Prawo o postępowaniu przed sądami administracyjnymi i jako taki nie powinien być interpretowany rozszerzająco. Skarżący, który nie brał udziału w postępowaniu i któremu nie doręczono decyzji, może skorzystać z uprawnienia złożenia skargi przed upływem 30 dni od daty doręczenia decyzji innej stronie tego postępowania ${ }^{51}$.

Podkreślić wyraźnie należy, że przedmiotem zaskarżenia mogą być tylko decyzje - nie można wywodzić, że zaskarżeniu na podstawie przepisu art. 44 ust. 3 o udziale społeczeństwa podlegają akty prawa miejscowego $^{52}$. Należy mieć jednak na uwadze, że organizacja społeczna nie może zostać uczestnikiem takiego postępowania sądowoadministracyjnego,

50 Zob. tamże, s. 27.

51 Postanowienie NSA w Warszawie z dnia 19 kwietnia 2016 r., II OSK 2010/14, LEX nr 2065748; postanowienie WSA w Olsztynie z dnia 2 czerwca 2009 r., II SA/Ol 490/09, LEX nr 517520.

52 Postanowienie NSA w Warszawie z dnia 2 lutego 2010 r., II OSK 40/10, LEX nr 663576; postanowienie WSA we Wrocławiu z dnia 5 września 2017 r., II SA/Wr 383/17, LEX nr 2353802. 
które dotyczy kontroli decyzji wydanej w postępowaniu, w którym ustawodawca wykluczył udział organizacji społecznych ${ }^{53}$.

\section{Wykładnia odpowiedniego stosowania przepisów prawnych w postępowaniu wymagającym udziału społeczeństwa}

Instytucja prawna, jaką jest udział społeczeństwa w ochronie środowiska, została objęta kompleksową regulacją prawną. Należy zatem zwrócić uwagę również na kwestię odpowiedniego stosowania przepisów pozwalających na odmowę udostępnienia wnioskowanych informacji do prowadzenia postępowań wymagających udziału społeczeństwa (art. 16-20 u.o.o.ś.). Jak słusznie wskazuje się w literaturze przedmiotu, wprowadzenie wskazanej regulacji prawnej sprawia, że udział społeczeństwa ma charakter rzeczywisty i autentyczny, gdyż społeczeństwo uzyskuje dostęp do informacji istotnych dla konkretnego postępowania ${ }^{54}$.

W pierwszej kolejności należy wskazać, na czym polega odpowiednie stosowanie przepisów. Z analizy orzecznictwa ${ }^{55}$ wynika, że odpowiednie stosowanie przepisów prawa oznacza: stosowanie odnośnych przepisów bez żadnych zmian do innego zakresu odniesienia, stosowanie ich z pewnymi zmianami albo niestosowanie tych przepisów do innego zakresu odniesienia. Ostatni ze wskazanych wariantów znajduje zastosowanie wyłącznie w sytuacji wystąpienia sprzeczności lub bezprzedmiotowości z przepisami ustanowionymi dla tych instytucji, do których mają one być stosowane odpowiednio ${ }^{56}$. Jednocześnie warto dodać, że w niektórych sytuacjach przepisy regulujące daną materię samodzielnie kształtują określone kwestie proceduralne modyfikując procedurę wyznaczoną przez przepisy stosowane odpowiednio ${ }^{57}$. Reasumując, należy wskazać,

53 Postanowienie WSA w Poznaniu z dnia 20 stycznia 2009 r., II SA/Po 889/08, LEX nr 487497.

54 Zob. K. Gruszecki, Ustawa o udostępnianiu informacji..., s. 101-102; M. Słaby [w:] B. Opaliński (red.), Ustawa o udostępnianiu informacji..., s. 91-92.

55 Zob. uchwała SN z dnia 23 sierpnia 2006 r., III CZP 56/06, OSNC 2007, nr 3, poz. 43; wyrok WSA w Kielcach z dnia 21 marca 2013 r., II SA/Ke 119/13, LEX nr 1299528; wyrok SN z dnia 15 lutego 2008 r., I CSK 357/07, LEX nr 394763.

56 Zob. M. Słaby [w:] B. Opaliński (red.), Ustawa o udostępnianiu informacji..., s. 91-92.

57 Zob. wyrok WSA w Kielcach z dnia 21 marca 2013 r., II SA/Ke 119/13, LEX nr 1299528. 
że stosowanie „odpowiednie” nie zawsze oznacza stosowanie bez zmian. Rozważenia wymagają względy swoistości postępowania toczącego się z udziałem społeczeństwa.

Wskazać należy, że z odpowiednim stosowaniem mamy do czynienia w sytuacji, gdy w postępowaniu wymagającym udziału społeczeństwa podmiot jednocześnie żąda uzyskania informacji o środowisku i jego ochronie. $W$ rezultacie osoba składająca uwagi i wnioski pełni rolę wnioskodawcy $\mathrm{w}$ ramach korzystania $\mathrm{z}$ prawa dostępu do informacji o środowisku i jego ochronie. Zasygnalizować należy, że przepisy art. 16-20 u.o.o.ś. dotyczą przesłanek odmowy udostępnienia informacji o środowisku, możliwości ich wyłączenia, formy i zaskarżenia odmowy udostępnienia informacji o środowisku i jego ochronie oraz czynności podczas niej podejmowanych. Na gruncie obecnie obowiązującego stanu prawnego wszystkie przesłanki odmowy udostępnienia informacji o środowisku mają charakter wyłącznie fakultatywny. Jednak należy zauważyć, że w przypadku przesłanek z art. 16 ust. 1 u.o.o.ś. (np. możliwość naruszenia bezpieczeństwa publicznego, obronności i bezpieczeństwa państwa lub ochrony danych przewidzianej przepisami o ochronie informacji niejawnych) obowiązkiem władz publicznych jest rozważenie interesu publicznego przemawiającego za udostępnieniem informacji w konkretnym przypadku. Tytułem podsumowania należy wskazać, że przesłanki odmowy udostępnienia informacji o środowisku i jego ochronie z art. 16 ust. 1 i 2 u.o.o.ś., stanowiące wyjątki od prawa przyznanego zarówno przepisami u.o.o.ś., jak i Konstytucji RP, nie podlegają wykładni rozszerzającej58.

W przypadku udziału społeczeństwa, stanowiącego przedmiot niniejszych rozważań, główną różnicą wpływającą na sposób odpowiedniego stosowania innego zakresu odniesienia jest to, że w określonych kategoriach spraw informacje są udostępnianie $\mathrm{w}$ ramach prowadzonego postępowania $^{59}$. Podkreślić należy, że samo żądanie udostępnienia informacji o środowisku i jego ochronie złożone $\mathrm{w}$ formie wniosku nie powoduje wszczęcia postępowania administracyjnego. Dopiero w przypadku wydania decyzji odmownej na udzielenie informacji o środowisku i jego ochronie jej adresat staje się stroną postępowania, ale jedynie w zakresie postępowania dotyczącego wnioskowanej informacji. Dodatkowo należy

58 Zob. wyrok SN z dnia 4 lutego 2000 r., II CKN 738/98, OSNC 2000, nr 7-8, poz. 146; uchwała SN z dnia 18 kwietnia 2000 r., III CZP 9/00, OSNC 2000, nr 9, poz. 153.

59 Zob. K. Gruszecki, Ustawa o udostepnianiu informacji..., s. 101-102. 
wskazać, że udział społeczeństwa może przyjąć formę składania uwag i wniosków, jak też dopuszczenia do udziału w postępowaniu na prawach strony. Jednak samo zgłoszenie uwag i wniosków nie jest równoznaczne $\mathrm{z}$ uczestnictwem $\mathrm{w}$ postępowaniu, chociaż nie ulega wątpliwości, że składane są one w postępowaniu już prowadzonym wobec innych podmiotów.

\section{Zakończenie}

Podsumowując, należy wskazać, że stosowanie przepisów w zakresie udziału społeczeństwa w ochronie środowiska powinno uwzględniać cele analizowanej regulacji. Uzyskać taki efekt można m.in. poprzez wykorzystanie $\mathrm{w}$ procesach interpretacji tych przepisów wykładni celowościowo-funkcjonalnej, które pozwalają na ewentualną weryfikację ustaleń wykładni językowej oraz systemowej.

Warte zasygnalizowania jest również to, że podczas interpretacji ustaleń terminologicznych dotyczących partycypacji publicznej w ochronie środowiska (,każdy”, "cele statutowe”, ,postępowanie wymagające udziału społeczeństwa") stosowana jest wykładnia rozszerzająca. Tylko w przypadku pojęcia „organizacja ekologiczna” jednoznaczność została uzyskana za pomocą dyrektyw językowych.

Na zakończenie należy powołać się również na swoistość postępowania toczącego się z udziałem społeczeństwa, która implikuje konieczność odpowiedniego stosowania przepisów o odmowie udostępnienia informacji o środowisku i jego ochronie, jeżeli w postępowaniu wymagającym udziału społeczeństwa podmiot jednocześnie żąda uzyskania takiej informacji. Podsumowując kwestię interpretacji w tym zakresie, warto wskazać również na dopuszczalność przeprowadzenia wyłącznie literalnej wykładni przesłanek odmowy udostępnienia informacji o środowisku i jego ochronie.

Słowa kluczowe: wykładnia, udział społeczeństwa w ochronie środowiska 


\section{Bibliografia}

\section{Źródła}

\section{Akty prawne}

Konstytucja Rzeczypospolitej Polskiej z dnia 2 kwietnia 1997 r., Dz. U. z 1997 r. Nr 78, poz. 483 z późn. zm.

Ustawa z dnia 14 czerwca 1960 r. - Kodeks postępowania administracyjnego, tekst jednolity: Dz. U. z 2017 r. poz. 1257.

Ustawa z dnia 3 października 2008 r. o udostępnianiu informacji o środowisku i jego ochronie, udziale społeczeństwa w ochronie środowiska oraz o ocenach oddziaływania na środowisko, tekst jednolity: Dz. U. z 2018 r. poz. 2081 z późn. zm.

\section{Orzecznictwo}

Postanowienie NSA w Warszawie z dnia 2 lutego 2010 r., II OSK 40/10, LEX nr 663576.

Postanowienie NSA w Warszawie z dnia 19 kwietnia 2016 r., II OSK 2010/14, LEX nr 2065748.

Postanowienie WSA w Olsztynie z dnia 2 czerwca 2009 r., II SA/Ol 490/09, LEX nr 517520.

Postanowienie WSA w Poznaniu z dnia 20 stycznia 2009 r., II SA/Po 889/08, LEX nr 487497.

Postanowienie WSA we Wrocławiu z dnia 5 września 2017 r., II SA/Wr 383/17, LEX nr 2353802.

Wyrok NSA w Warszawie z dnia 13 grudnia 2011 r., II OSK 1732/10, LEX nr 1152019.

Wyrok NSA w Warszawie z dnia 9 kwietnia 2013 r., II OSK 2396/11, LEX nr 1337355.

Wyrok NSA w Warszawie z dnia 15 maja 2008 r., II OSK 548/07, Centralna Baza Orzeczeń Sądów Administracyjnych (CBOSA), http://orzeczenia.nsa.gov. pl/doc/F460921839 [dostęp: 13.11.2018 r.].

Wyrok NSA w Warszawie z dnia 21 czerwca 2016 r., II OSK 2563/14, LEX nr 2106685.

Wyrok NSA w Warszawie z dnia 9 sierpnia 2016 r., II OSK 2237/15, LEX nr 2142364.

Uchwała SN z dnia 18 kwietnia 2000 r., III CZP 9/00, OSNC 2000, nr 9, poz. 153.

Uchwała SN z dnia 12 grudnia 2005 r., II OPS 4/05, LEX nr 167966.

Uchwała SN z dnia 23 sierpnia 2006 r., III CZP 56/06, OSNC 2007, nr 3, poz. 43.

Wyrok SN z dnia 4 lutego 2000 r., II CKN 738/98, OSNC 2000, nr 7-8, poz. 146.

Wyrok SN z dnia 15 lutego 2008 r., I CSK 357/07, LEX nr 394763.

Wyrok TK z dnia 25 lutego 1992 r., K 3/91, OTK 1992, nr 1, s. 34. 
Wyrok WSA w Gorzowie Wielkopolskim z dnia 13 października 2017 r., II SA/ Go 889/17, LEX nr 2387827.

Wyrok WSA w Kielcach z dnia 21 marca 2013 r., II SA/Ke 119/13, LEX nr 1299528. Wyrok WSA w Kielcach z dnia 4 grudnia 2013 r., II SA/Ke 920/13, LEX nr 1426855. Wyrok WSA w Kielcach z dnia 28 czerwca 2017 r., II SA/Ke164/17, LEX nr 2325102.

Wyrok WSA w Szczecinie z dnia 14 stycznia 2016 r., II SA/Sz 1097/15, LEX nr 1996661.

Wyrok WSA w Warszawie z dnia 11 sierpnia 2010 r., IV SA/Wa 857/10, LEX nr 759044.

Wyrok NSA z dnia 29 listopada 2016 r., II OSK 524/15, CBOSA.

Wyrok WSA we Wrocławiu z dnia 27 maja 2010 r., II SA/Wr 89/10, LEX nr 674622.

\section{Literatura}

Borkowski J., Glosa do wyroku NSA z dnia 23 listopada 1999 r., II SA Kr 1191/99, „Orzecznictwo Sądów Polskich” 2000, z. 7/8, poz. 112.

Brzeziński B., Wstęp do nauki prawa podatkowego, Torun 2003.

Draniewicz B., Glosa do wyroku WSA z dnia 22 lipca 2012 r., II Sa/Kr 272/10, „Prawo i Środowisko" 2010, nr 3, s. 110-119.

Florczak-Wątor M. [w:] M. Safjan, L. Bosek (red.), Konstytucja RP. Komentarz, t. 1, Warszawa 2016, s. 1451.

Górski M., Aktualne regulacje prawne w zakresie ochrony środowiska, wedtug stanu prawnego na koniec stycznia 2009 r., Poznań 2009.

Górski M. [w:] J. Jendrośka (red.), Ustawa - Prawo ochrony środowiska. Komentarz, Wrocław 2001, s. 53-57.

Górski M., M. Pchałek, W. Radecki, J. Jerzmański, M. Bar, S. Urban, J. Jendrośka, Prawo ochrony środowiska. Komentarz, Warszawa 2011.

Gruszecki K., Ustawa o udostępnianiu informacji o środowisku i jego ochronie, udziat społeczeństwa w ochronie środowiska oraz oceny oddziaływania na środowisko. Komentarz, Wrocław 2009.

Haładyj A., Udział społeczeństwa w strategicznej ocenie oddziatywania na środowisko jako instytucji prawa ochrony środowiska, Lublin 2015.

Jakimowicz W., Wykładnia w prawie administracyjnym, Warszawa 2006.

Jamroza A. (red.), Wstęp do nauk prawnych, Białystok 1997.

Korycki S., J. Kuciński, Z. Trzciński, J. Zaborowski, Zarys prawa, Warszawa 2005.

Korzeniowski P., Instytucje prawne ochrony środowiska a proces inwestycyjno-budowlany. Studium prawno-administracyjne, Warszawa 2012.

Korzeniowski P., Zasady prawne ochrony środowiska, Łódź 2010.

Kościuk D. [w:] T. Filipowicz, A. Plucińska-Filipowicz, M. Wierzbowski (red.), Ustawa o udostępnianiu informacji o środowisku i jego ochronie, udziat społeczeń- 
stwa w ochronie środowiska oraz oceny oddziatywania na środowisko. Komentarz, Warszawa 2017, s. 210-213.

Jacyno W., J. Rewkowska [w:] T. Filipowicz, A. Plucińska-Filipowicz, M. Wierzbowski (red.), Ustawa o udostęnianiu informacji o środowisku i jego ochronie, udziat społeczeństwa w ochronie środowiska oraz oceny oddziaływania na środowisko. Komentarz, Warszawa 2017, s. 52-53.

Leszczyński L., Wykładnia celowościowo-funkcjonalna przepisów prawa administracyjnego, [w:] R. Hauser, Z. Niewiadomski, A. Wróbel (red.), System prawa administracyjnego, t. 4. L. Leszczyński, B. Wojciechowski, M. Zirk-Sadowski, Wykładnia w prawie administracyjnym, Warszawa 2012, s. 263-303.

Leszczyński L., Wykładnia systemowa przepisów prawa administracyjnego, [w:] R. Hauser, Z. Niewiadomski, A. Wróbel (red.), System prawa administracyjnego, t. 4. L. Leszczyński, B. Wojciechowski, M. Zirk-Sadowski, Wykładnia w prawie administracyjnym, Warszawa 2012, s. 209-261.

Leszczyński L., Zagadnienia teorii stosowania prawa. Doktryna i tezy orzecznictwa, Kraków 2001.

Morawski L., Kilka uwag na temat wykładni, [w:] S. Wronkowska (red.), Polska kultura prawna a proces integracji europejskiej, Kraków 2005, s. 42.

Nowak M., B. Dąbrowski, Ustawa o udostepnianiu informacji o środowisku i jego ochronie, udział społeczeństwa w ochronie środowiska oraz oceny oddziaływania na środowisko. Komentarz praktyczny, Warszawa 2013.

Opaliński B. [w:] B. Opaliński (red.), Ustawa o udostepnianiu informacji o środowisku i jego ochronie, udział społeczeństwa w ochronie środowiska oraz oceny oddziatywania na środowisko. Komentarz, Warszawa 2016, s. 91-92.

Rakoczy B. [w:] Z. Bukowski, E.K. Czech, K. Karpus, B. Rakoczy, Prawo ochrony środowiska. Komentarz, Warszawa 2013, s. 50-51.

Rakoczy B. [w:] J. Ciechanowicz-McLean, Z. Bukowski, B. Rakoczy, Prawo ochrony środowiska. Komentarz, Warszawa 2008, s. 47-48.

Statut, [w:] Słownik jezzyka polskiego, PWN, http://sjp.pwn.pl/sjp/;2524005 [dostęp: 11.12.2017 r.].

Zakrzewska M., Skarga powszechna w prawie ochrony środowiska, [w:] M. Rudnicki, A. Haładyj, K. Sobieraj (red.), Dekada harmonizacji w prawie ochrony środowiska, Lublin 2011, s. 81.

Zieliński M., Wybrane zagadnienia wykładni prawa, „Państwo i Prawo” 2009, nr 6, s. 8.

Zieliński M., Wykładnia prawa. Zasady, reguły, wskazówki, Warszawa 2010.

Ziembiński Z., Zadania i moc wiążąca aktów wykładni, [w:] S. Wronkowska, Z. Ziembiński, Zarys teorii prawa, Poznań 1997, s. 160.

Zirk-Sadowski M., Problemy wykładni jezykowej w prawie administracyjnym, [w:] R. Hauser, Z. Niewiadomski, A. Wróbel (red.), System prawa administracyjnego, t. 4. L. Leszczyński, B. Wojciechowski, M. Zirk-Sadowski, Wykładnia w prawie administracyjnym, Warszawa 2012, s. 179-208. 


\section{INTERPRETATION OF LEGAL PROVISIONS CONCERNING PUBLIC PARTICIPATION IN ENVIRONMENTAL PROTECTION - SELECTED PROBLEMS}

\section{Sum mary}

The article presents some selected problems related to the interpretation of legal regulations concerning public participation in environmental protection. Particular attention was given to the more important terms related to the titular issue. It is important to highlighted, that doubts concerning the accordingly application of legal provisions in proceedings requiring public participation were also considered.

Key words: interpretation, public participation in environmental protection

\section{ИНТЕПРЕТАЦИЯ ПОЛОЖЕНИЙ В СФЕРЕ УЧАСТИЯ ОБЩЕСТВА В ОХРАНЕ ОКРУЖАЮЩЕЙ СРЕДЫ - ИЗБРАННЫЕ ПРОБЛЕМЫ}

\section{Резюме}

Статья демонстрирует избранные проблемы, связанные с интерпретацией положений, которые относятся к публичному финансовому участью в охране окружающей среды. К анализу были подвергнуты более важные понятия, связанные с проблематикой относительно заголовка стати. Также, обращая внимание на сомнения, которые касаются соответствующего применения правовых положений в производстве, которое нуждается в участии общества.

Ключевые слова: интерпретация, участие общества в охране окружающей среды 